\title{
The Influence of School Entry Skills in Literacy and Numeracy on the Science Achievement of Fourth Grade Students and Schools in Asian Regions
}

\author{
Yu Chen ${ }^{1}$, Chorng-Jee Guo ${ }^{2}$, Kam Ming Lim ${ }^{3}$, Kong-Ju Mun ${ }^{4}$, Hisashi Otsuji ${ }^{5}$, Young-Shin Park ${ }^{6}$, \\ David Sorrell ${ }^{7}$, Wing Mui Winnie So ${ }^{1 *}$ \\ ${ }^{1}$ The Education University of Hong Kong, HONG KONG \\ ${ }^{2}$ National Changhua University of Education, TAIWAN \\ ${ }^{3}$ Nanyang Technological University, SINGAPORE \\ ${ }^{4}$ Seoul National University, SOUTH KOREA \\ ${ }^{5}$ Toyo University, JAPAN \\ ${ }^{6}$ College of Education, Chosun University, SOUTH KOREA \\ 7 Independent Education Consultant, HONG KONG
}

Received 1 August 2019 - Accepted 6 June 2020

\begin{abstract}
This study examined the associations between school entry skills and science achievement at both the student and school levels among fourth-grade students in South Korea, Singapore, Japan, Chinese Taipei, and Hong Kong. Data of the five Asian regions in the 2015 Trends in International Mathematics and Science Study (TIMSS) were analysed. Variables included Interest, Self-concept, School entry skills - reported by parents, Cognitive activities, Parent attitudes toward mathematics and science, Home educational resources, and Gender, all at the student level, and Emphasis on academic success, Discipline problems, and School entry skills - reported by principals at the school level. Results of the multilevel path analysis indicated that School entry skills positively and directly influenced science achievement, and simultaneously mediated the influence from cognitive activities to science achievement at the student level. These findings were consistent among the five Asian regions. At the school level, it was found that compared to School entry skills, School emphasis on academic success was the stronger predictor of science achievement among students for most Asian regions. Implications for improving primary school students' science learning are discussed.
\end{abstract}

Keywords: science achievement, school entry skills, multilevel path analysis

\section{INTRODUCTION}

Why Asian students always perform so well in international tests (e.g. PISA, TIMSS) has attracted great attention worldwide. Indeed, the results from TIMSS 2015 (Martin, Mullis, Foy, \& Hooper, 2017) showed that Asian regions (South Korea, Japan, Singapore, Chinese Taipei, and Hong Kong) consistently dominated the top of the TIMSS rankings and out-performed other participating regions.

School entry skills are considered as essential for academic performance. In Asian contexts, it is commonly believed by Asian parents that the extent to which their children can do well in literacy and numeracy tasks at the point of school entry largely determine the schools their children can be enrolled in, which may greatly influence their children's future study and careers. For schools, places are allocated largely based on students' cognitive abilities, and this leads to schools in some Asian regions (e.g. Hong Kong, Singapore) becoming more academically segregated. Given this background, it is possible that great school entry skills in literacy and numeracy among Asian students account for their science achievement, as well as the differences in science achievement between schools. However, whether this is indeed the case, and the extent to which excellent science performance at the individual and school levels can be

(c) 2020 by the authors; licensee Modestum. This article is an open access article distributed under the terms and conditions of the Creative Commons Attribution License (http://creativecommons.org/licenses/by/4.0/). 


\section{Contribution to the literature}

- School entry skills were an important predictor of science achievement among Asian students. It was consistent across the Asian regions that school entry skills influenced self-concept and science achievement positively and directly at the student level.

- School entry skills also play a major role in mediating the relationship between family support and science achievement at the student level. Sufficient educational resources and activities led to improved literacy/numeracy skills and subsequently science learning.

- At the school level, emphasis on academic success was more predictive of school average science achievement than school entry skills.

explained by Asian students' early literacy and numeracy skills remain unexplored.

This study, therefore, explored the associations between School entry skills and science achievement at both student and school levels. Data of fourth-grade students in the above-mentioned five Asian regions in the TIMSS 2015 were subjected to multi-group multilevel path analysis. The comparison in different Asian contexts helps to shed light on the role of School entry skills in transnational variations in science achievement.

\section{LITERATURE REVIEW}

\section{Transnational Comparisons of Factors that Would Influence Science Achievement}

Great effort has been made to identify the factors at multiple levels that influence students' success in science learning (Grabau \& Ma, 2017; House \& Telese, 2013; Tsai \& Yang, 2015). Several recent studies (e.g. Ker, 2017; Mohammadpour, Shekarchizadeh, \& Kalantarrashidi, 2015; Topçu, Erbilgin, \& Arikan, 2016; Wang \& Bergin, 2017) have explored factors predicting differences in science achievement between countries, suggesting that factors at the student level (e.g. liking learning science, self-concept, gender, socio-economic status, instruction) and those at the school level (e.g. school climate, location) are essential for academic performance across countries.

Topçu et al. (2016) explored how nine factors related to student aptitude, instruction, and environment predicted the science achievement of students in Turkey and the Republic of Korea in the 2011 TIMSS based on Walberg's model of educational productivity, and found that valuing science, self-efficacy, teacher effectiveness, and parental educational level contributed significantly to South Korean students' science achievement. Mohammadpour et al. (2015) investigated variability in the science achievement of students in 29 countries / regions who participated in the 2007 TIMSS. Multilevel modelling results showed that science achievement was largely determined by student level factors including self-concept, family background, gender, and time spent on nonacademic activities in these countries/regions, except for Malaysia, Hong Kong, and Singapore. At the school level, a positive school climate and good school attendance showed a significant link to achievement. Moreover, this study found that the percentage of GDP spent on education and the rate of enrolment at secondary school accounted for the differences in achievement between the countries/regions.

However, these studies were limited to identifying potential predictors of science achievement using hierarchical linear modelling and multilevel regression modelling, without in-depth exploration of the underlying path associations among these factors and science achievement. Research using other statistical methods (e.g. path analysis) to provide further insights into the mechanisms of how science learning would be affected or mediated by individual, family or school factors at different levels of an educational system are needed, as this they are important for developing approaches which more effectively increase students' success in science (Duschl, Schweingruber, \& Shouse, 2007).

On the other hand, it was noted that in the recent TIMSS 2015, the students in Asian regions including South Korea, Japan, Singapore, Chinese Taipei, and Hong Kong consistently topped the list of the TIMSS participating countries/regions. In addition, the students in these regions were reported as doing extremely well on literacy and numeracy tasks when they began primary school. Investigating the relationships between school entry skills and individual and school science achievement in these regions may provide more insights into the reasons why Asian students always rank top in the TIMSS. The findings might shed light on the promotion of more effective initiatives to enhance students' achievement levels.

Although the Asian educational systems have much in common, such as a centralised education system and public expenditure on education (Jeynes, 2008), their respective uniqueness relevant to student achievement still warrants close attention (Chen, 2014). For instance, the educational competition in Japan and South Korea is relatively less drastic than in Hong Kong and Chinese Taipei (Yang, 1998). The 'exam hell' drives East Asian students to study longer and harder, but Japan may soon become an exception (Komatsu \& Rappleye, 2018). Therefore, this study intended to explore whether the 
relationships between school entry skills and science achievement are invariant across Asian regions.

\section{School Entry Skills and Later Science Achievements}

A number of studies (e.g. Shanley, Clarke, Doabler, Kurtz-Nelson, \& Fien, 2017; Zhu \& Chiu, 2019) have focused on the predictive role of early mathematics and learning skills on students' later mathematics and reading achievement. For instance, a meta-analysis by Duncan et al. (2007) indicated that skills in literacy and numeracy at the point of school entry were closely linked to academic performance in later grades. Davies, Janus, Duku, and Gaskin (2016) found that early mathematics and learning skills were generally important predictors of reading, writing and mathematics. Compared to students who entered formal schooling with mathematics and reading skills, those without may continue to lag behind expected levels of academic performance, or choose school retention (Davoudzadeh, McTernan, \& Grimm, 2015).

A relatively limited number of studies have been conducted which link literacy and numeracy skills to children's science learning. Barnard-Brak, Stevens, and Ritter (2017) emphasized the importance of reading and mathematics in the prediction of science achievement. Claessens and Engel (2013) found that early mathematics knowledge and skills in pattern recognition, measurement, and advanced number are predictive of later mathematics achievement but also of achievement in science. Blums, Belsky, Grimm, and Chen (2017) also demonstrated that skills such as verbal counting in kindergarten would contribute to mathematics problemsolving that would support high school STEM achievement (science, technology, engineering, and mathematics).

Moreover, little is known regarding whether school entry skills in literacy and numeracy would have indirect impacts on science achievement. Research has suggested that prior cognitive skills may be related to the foundation of interest (a preference for taking on a challenging task and being driven by interest and curiosity) and/or self-concept (beliefs about personal competence in learning) (Walgermo, Foldnes, Uppstad, \& Solheim, 2018). For instance, reading skills at school entry might affect children's subsequent self-concept in reading after one year of reading instruction (Walgermo et al., 2018). Other studies have documented that interest and/or self-concept play critical roles in science achievement (e.g. Liou, 2017; Mohammadpour, 2013; Wang \& Liou, 2017) and in mediating the relations between factors such as gender and socioeconomic status (SES) with academic achievement (e.g. De la Fuente, Sander, \& Putwain, 2013; Grolnick, Friendly, \& Bellas, 2009; Parker et al., 2012). However, Yu (2012) revealed that the science competency of East Asian students was not related to their interest or perceived ability in learning science. Therefore, it is not conclusive whether the influence of Asian students' school entry skills and science achievement would be through interest and self-concept.

\section{Family influences on Skills Acquisition and Science Achievement}

There has been a growing body of research on the role of family support in children's academic performance. Boulifa and Kaaouachi (2015) investigated the effect of Home resources for learning on the science performance of Moroccan fourth-grade students. The results of their multilevel analysis based on TIMSS 2011 showed that home education resources were positively correlated with student achievement. Sun, Bradley, and Akers (2012) and Thomas and Strunk (2017) indicated that parental attitude toward science greatly impacted students' achievement through analyzing the PISA data.

Several studies have suggested a number of family factors that may influence students' early literacy and numeracy acquisition, such as the quality of the home learning environment (Dearing, McCartney, \& Taylor, 2012), parental academic expectations (Park \& Kim, 2006; Segers, Kleemans, \& Verhoeven, 2015), and parentprovided early reading and mathematics experiences (Huntsinger, Jose, \& Luo, 2016; Skwarchuk, Sowinski, \& LeFevre, 2014). A review study of Park and Kim (2006) indicated that South Korean parents highly agreed with the value of academic achievement and showed strong educational aspirations for their children. Support from parents was essential for South Korean students' development and academic success. In the Japanese context, disadvantages in family background were found to have negative impacts on students' learning outcomes, causing widening bipolarisation in early academic knowledge or skills among students (Katsuno, 2019). Zhu and Chiu (2019) showed that Hong Kong students' early numeracy acquisition positively mediated the relation between early numeracy activities at home and mathematics achievement among Hong Kong students, although this mediation effect was minor compared to that of self-concept. However, whether these findings can be generalisable to other subjects such as science has yet to be investigated.

\section{School Entry Skills and School Average Achievement}

In TIMSS 2015, students' school entry skills at the school level were scored according to the principals' reports on the percentage of students in the school who began first grade with key skills in literacy and numeracy. However, research into the extent to which school entry skills result in differences in science achievement between schools is relatively limited compared to the large body of research focusing on the impacts of school safety, school resources, and location on achievement using the TIMSS data. 


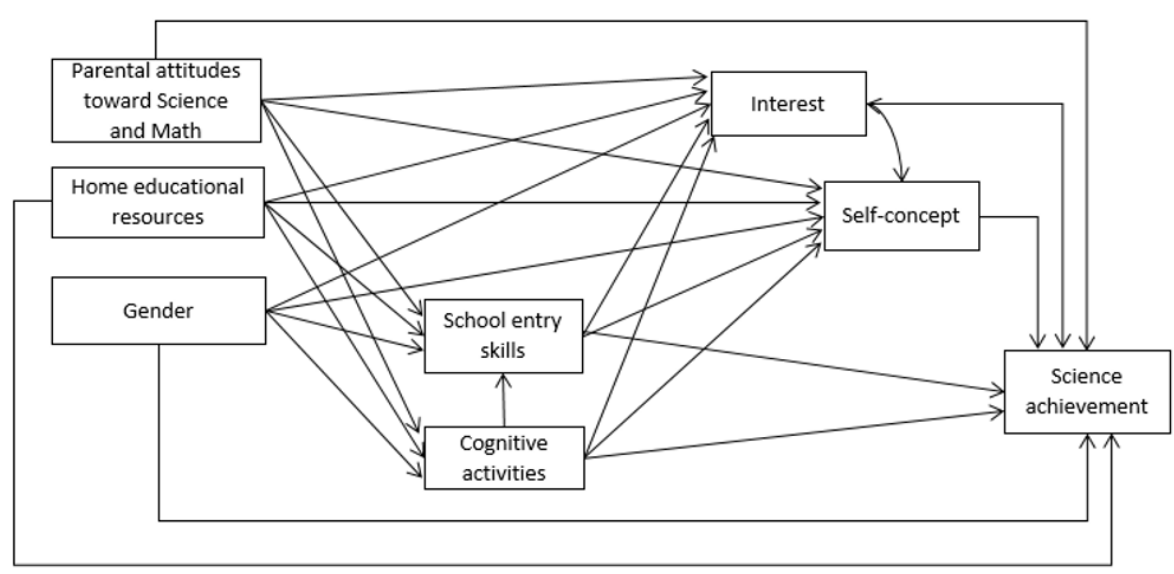

Student leve

School level

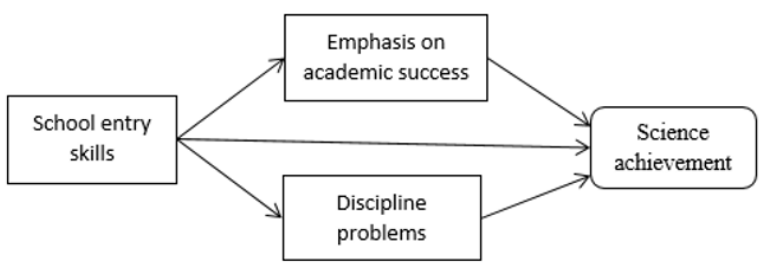

Figure 1. The hypothesized multilevel path analysis model

One study by Lam and Lau (2014) found that school student intake was a strong predictor of school average achievement in science. When taking into account the average academic levels of students in each school, the effect of school SES was insignificant, and the effect of school enrollment size was much smaller. They explained that one important reason for this was the admission system in Hong Kong which commonly allows schools to enroll students based on their academic ability, sibling policy, and religion. Schools are heavily academically segregated, because 'band 1 schools' (best student intake) that are favored by parents are able to enroll more academically strong students, while schools with low student intake have much more difficulty doing so.

Similarly, in Singapore, overt social selection occurs as well, with top schools choosing top students. Singapore's policy for enhancing school choice seems to add such social selection, exacerbating school segregation by student performance levels (Vidovich \& Sheng, 2008). In South Korea, students are generally assigned to neighborhood schools for primary education, but they are also allowed to choose schools, which may still lead to increased segregation between schools as school choice increases (Byun, Kim, \& Park, 2012). In Japan, there is a school choice system to ensure that students attend certain schools. However, schools have authority over selection of students, typically referring to entrance examination scores (Dierkes, 2008; Omomo, 2019). Therefore, it is worth examining whether there has been an invariance in the influence of school entry skills on schools with respect to science achievement across Asian regions, by extending the examination of such influence to Asian contexts in addition to Hong Kong. Additionally, this study included school emphasis on academic success and discipline problems. It was assumed that schools with more students with literacy and numeracy skills are likely to show higher expectations of academic success and have fewer discipline problems, which are both positively linked to higher school average achievement in science.

\section{METHODS}

The purpose of this study was to explore the associations between several student and school level factors and the science performance of fourth graders in South Korea, Japan, Singapore, Chinese Taipei, and Hong Kong based on the TIMSS 2015 data.

The research questions included:

1. Do School entry skills significantly and positively influence Interest, Self-concept, and science achievement at the student level?

2. Do School entry skills mediate the influence of Family support (Cognitive activities, Parental attitudes, Home educational resources) on Interest, Self-concept, and science achievement at the student level?

3. Do School entry skills influence School emphasis on/expectation of academic success and Discipline problems, and science achievement at the school level?

Figure 1 shows the hypothesised multilevel model of science achievement in each region with an assumption that all the factors directly influence science 
Table 1. Number of sampled students and schools in each region

\begin{tabular}{lll}
\hline Regions & No. of students & No. of schools \\
\hline South Korea & 4669 & 149 \\
Japan & 4383 & 148 \\
Singapore & 6517 & 139 \\
Chinese Taipei & 4291 & 150 \\
Hong Kong & 3600 & 132 \\
\hline
\end{tabular}

achievement. The hypotheses were that (1) School entry skills influence science achievement directly and indirectly through Interest and Self-concept; (2) the connections of Cognitive activities, Parental attitudes, Home educational resources, and Gender with science achievement are due to the positive effects that School entry skills have on Interest, Self-concept, and Science learning at the student level; and (3) at the school level, School entry skills influence School-mean science achievement not only directly, but also indirectly through Emphasis on Academic success and Discipline Problems.

\section{Data Source and Sample}

The data of 23,460 fourth-grade students from 718 schools in South Korea, Japan, Singapore, Chinese Taipei, and Hong Kong in the TIMSS 2015 were analysed. The selection of accurate and representative samples followed a two-stage sampling procedure, in which the first stage comprised a sample of schools and the second comprised a single class selected randomly from the sampled schools (Martin, Mullis, \& Hooper, 2016). Table 1 presents the number of sampled students and schools in each region.

\section{Variables}

Based on item response theory, TIMSS provided five plausible values (PV) as science achievement, which refer to five estimations of student achievement score. The use of plausible values helped to "ensure the accuracy of estimates of the proficiency distributions for the TIMSS populations as a whole and particularly for comparisons between subpopulations" (Martin et al., 2016, Chapter 12.7). It is also stated by Foy $(2017$, p. 55) that "The plausible values for any given scale are the best available measures of student achievement on that scale in the TIMSS 2015 international database, and should be used as the outcome measure in any study of student achievement". Hence, this study used the five plausible values as a proxy for science achievement (the dependent variable). For the independent variables, there were seven student-level factors (Interest, Selfconcept, School entry skills - reported by parents, Cognitive activities, Parental attitude, Home resources, and Gender) and three school-level factors (Emphasis on success, Discipline problems, and School entry skills reported by principals). Relevant scales were selected from the TIMSS 2015 Student-background, Home and
School questionnaire (Martin et al., 2016). A description of these scales is presented in Appendix A.

\section{Data Analysis}

One-way ANOVA was first run to test whether there were significant differences in School Entry skills by region. Analyses of the associations between School entry skills and science achievement at both the student and school levels in each of the five Asian regions were conducted using multi-level multi-group path analysis via Mplus 8.0. In order to compare whether the hypothesised path model (Figure 1) remained unchanged among different regions, two multilevel path analysis models were established, an unconstrained model (all path coefficients were set as free across the five regions) and a fully constrained model (all path coefficients were set as invariant across the five regions). Changes in Chi-square $\left(x^{2}\right)$ and CFI were used to evaluate invariance in the multi-group modelling. Nonsignificant difference in $\chi^{2}(p>.05)$ and changes in CFI of less than 0.01 would indicate that the path coefficients of the models were invariant across groups, leading to the acceptance of the fully constrained model (Wang \& Wang, 2012). In contrast, if the unconstrained model was accepted, the Wald test was used to examine whether the influence of School entry skills on science achievement at the student level and the school level was invariant across regions.

Moreover, a multiple imputation (MI) procedure was employed to deal with missing values in the scales (Graham, 2009) and to explain uncertainty in the analysis of the plausible values (Mahler, Großschedl, \& Harms, 2017). To avoid the bias related to population characteristics, the total student weight (TOTWGT) provided as a part of the TIMSS database (Rutkowski, Gonzalez, Joncas, \& von Davier, 2010) was adopted.

\section{FINDINGS}

\section{Difference in School Entry Skills by Asian Regions}

Results of one-way ANOVA revealed significant differences in school entry skills by region $(F(4,23026)=$ $357.618, p<.001)$. Effect size $(\eta 2=.058)$ was medium (Cohen, 1988). Results of multiple comparison (Table 2) indicated that Singaporean and South Korean students performed literacy and numeracy tasks significantly better when they began primary school compared to those in the other regions, while Japanese students performed significantly less well. There were no significant differences in the proficiency of school entry skills among students from Hong Kong and Chinese Taipei. 
Table 2. Multiple comparison of School entry skills at the student-level by regions

\begin{tabular}{|c|c|c|c|c|c|c|}
\hline \multirow{2}{*}{ Variable } & \multicolumn{5}{|c|}{$M(S D)$} & \multirow{2}{*}{ Multiple comparison } \\
\hline & $\mathrm{HK}$ & KOR & $\mathrm{JP}$ & $\mathrm{TP}$ & SIG & \\
\hline $\begin{array}{l}\text { School entry } \\
\text { skills }\end{array}$ & $\begin{array}{l}10.98 \\
(2.39)\end{array}$ & $12.02(3.86)$ & $\begin{array}{c}8.13 \\
(2.92)\end{array}$ & $11.07(2.63)$ & $\begin{array}{l}11.27 \\
(3.30)\end{array}$ & $\begin{array}{c}\mathrm{KOR}>\mathrm{HK}^{* * *} ; \mathrm{KOR}>\mathrm{JP}^{* * *} ; \\
\mathrm{KOR}>\mathrm{TP}^{* * *} ; \mathrm{KOR}>\mathrm{SIG}^{* * *} ; \\
\mathrm{SIG}>\mathrm{HK}^{* * *} ; \mathrm{SIG}>\mathrm{JP}^{* * *} ; \\
\mathrm{SIG}>\mathrm{TP}^{* * *} ; \\
\mathrm{HK}>\mathrm{JP}^{* * *} ; \mathrm{TP}>\mathrm{JP}^{* * *} ;\end{array}$ \\
\hline
\end{tabular}

Noted: $M=$ Mean; $S D=$ standard deviation.

$* * * \mathrm{P}<0.001$

Table 3. Correlations of student- and school-level variables and science achievement

\begin{tabular}{lccccccc}
\hline Student-level variables & 1 & 2 & 3 & 4 & 5 & 6 & 7 \\
\hline 1. Interest & 1 & & & & & & \\
2. Science self-concept & $0.627 \mathrm{a}$ & 1 & & & & & \\
3. School entry skills - reported by parent & 0.019 & 0.079 & 1 & & & & \\
4. Cognitive activities & 0.040 & 0.087 & 0.365 & 1 & & & \\
5. Parental attitudes toward math/science & 0.082 & 0.059 & 0.130 & 0.163 & 1 & & \\
6. Home educational resources & 0.030 & 0.129 & 0.313 & 0.366 & 0.085 & 1 & \\
7. Gender & 0.100 & 0.086 & -0.070 & -0.018 & 0.026 & -0.003 & 1 \\
8. Science achievement & 0.154 & 0.248 & 0.358 & 0.235 & 0.136 & 0.450 & 0.048 \\
\hline School-level variables & 1 & 2 & 3 & 4 & & & \\
1. School emphasis on academic success & 1 & & & & & & \\
2. Discipline problems & 0.416 & 1 & & & & & \\
3. School entry skills - reported by principles & 0.336 & 0.224 & 1 & & & & \\
4. School-mean science achievement & 0.198 & 0.097 & 0.125 & 1 & & & \\
\hline
\end{tabular}

Note: a. all correlations are significant at 0.01 level ( 2 tailed)

Table 4. Model fit indices for unconstrained and constrained model

\begin{tabular}{lccccccc}
\hline \multirow{2}{*}{ Model fit indices } & \multirow{2}{*}{ Rf } & \multirow{2}{*}{$X^{2}$} & RMSEA & CFI & \multirow{2}{*}{ TLI } & \multicolumn{2}{c}{ SRMR } \\
\cline { 5 - 8 } & & & & & & within level & between level \\
\hline 1. Unconstrained model & 15 & 98.729 & 0.034 & 0.997 & 0.963 & 0.008 & 0.103 \\
2. Constrained model & 131 & 966.879 & 0.037 & 0.968 & 0.958 & 0.033 & 0.135 \\
\hline
\end{tabular}

\section{Correlations among variables and science achievement}

Table 3 presents the correlations among student and school level variables and science achievement. Overall, student level science achievement was more correlated with Home resources $(r s=.426)$ and School entry skills ( $r s=.356)$. The correlations between Self-concept and achievement ( $r s=.278$ ) were slightly stronger than those between Interest and achievement ( $r s=.173)$. Moreover, achievement was not strongly correlated with Cognitive attitudes $\left(r_{s}=.133\right)$ or with Parental attitude toward mathematics and science $(r s=.133)$. Besides, Self-concept and Interest were moderately correlated $(r s=0.625)$. The correlations between each two of School entry skills, Cognitive activities, and Home educational resources were $.365, .313$, and .366 , respectively.

At the school level, science achievement was correlated more strongly with School emphasis on academic success $(r s=.198)$ than with School entry skills $(r s=.125)$ and with Disciplinary problems ( $r s=.097)$. Besides, compared to the correlation with Discipline problems $\left(r_{s}=.336\right)$, the correlation of School entry skills with School emphasis on academic success was slighter stronger $(r s=.224)$.

\section{Model Fit}

Two models, the unconstrained model (path coefficients were set free across the five regions) and the constrained model (path coefficients were set equal across the five regions), were run. The model fit indices for both models are shown in Table 4 . These indices of both models met the criteria (CFI $>=0.90$; TLI $>=0.90$; RMSEA < 0.06) for acceptable model fit (Little, 2013). Comparing the two models, the unconstrained model was found to fit the data better with lower RMSEA and SRMR but had higher CFI and TLI. In addition, difference in $\chi^{2}$ followed a $\chi^{2}$ distribution $\left(\chi^{2}=966.879\right.$ $98.729=868.15)$ with a $d f$ of $(131-15)=116$ which was statistically significant $(p<.001)$. There was also a change in CFI which was larger than 0.01. These results indicated that the path coefficients of the model were non-invariant across the five regions. Therefore, the unconstrained model was finally accepted.

\section{Relations between School Entry Skills on Science achievement at the Student Level}

The results of the path analysis showed that School entry skills directly and positively influenced science achievement at the student level. School entry skills, 
Table 5. Standardized path coefficients of each model for each region

\begin{tabular}{|c|c|c|c|c|c|}
\hline Model & HK & KOR & $\mathrm{JP}$ & $\mathrm{TP}$ & SIG \\
\hline \multicolumn{6}{|l|}{ Student-level } \\
\hline \multicolumn{6}{|c|}{ Science achievement ON } \\
\hline Interest & $.079 * *$ & $.057^{*}$ & $.069^{* *}$ & -.03 & -.012 \\
\hline Self-concept & $.170 * * *$ & $.211^{* * *}$ & $.119 * * *$ & $.257^{* * *}$ & $.204^{* * *}$ \\
\hline School entry skills a & $.235^{\star * *}$ & $.181^{* * *}$ & $.234^{* * *}$ & $.167^{* * *}$ & $.298^{* * *}$ \\
\hline Cognitive activities & -.017 & .030 & -.011 & -.010 & $-.053^{* * *}$ \\
\hline Home resources $^{c}$ & $.179 * * *$ & $.306^{* * *}$ & $.296^{* * *}$ & $.331^{* * *}$ & $.354^{* * *}$ \\
\hline Parental attitude b & $.065^{* * *}$ & $.089 * * *$ & $.072^{* *}$ & .032 & .030 \\
\hline Gender & $.085^{* * *}$ & $.080^{* * *}$ & $.049 * *$ & $.064^{* * *}$ & .012 \\
\hline \multicolumn{6}{|l|}{ Interest ON } \\
\hline School entry skills & $.066^{* * *}$ & .021 & -.014 & .030 & .018 \\
\hline Cognitive activities & .026 & $.049 * *$ & .017 & .048 & $.043^{* *}$ \\
\hline Parental attitude & .021 & $.070^{* * *}$ & $.033^{*}$ & .027 & $.070^{* * *}$ \\
\hline Home resources & $.055^{*}$ & $.098^{* * *}$ & $.071^{* * *}$ & $.026^{*}$ & $.037^{*}$ \\
\hline Gender & $.099 * * *$ & $.112^{* * *}$ & $.113^{* * *}$ & $.106^{* * *}$ & $.073^{* * *}$ \\
\hline \multicolumn{6}{|l|}{ Self-concept ON } \\
\hline School entry skills & $.082^{* * *}$ & $.052^{* * *}$ & .018 & $.073^{* * *}$ & $.018^{*}$ \\
\hline Cognitive activities & $.057^{* *}$ & $.084^{* * *}$ & .033 & $.052^{* *}$ & $.043^{* *}$ \\
\hline Parental attitude & $.051^{* *}$ & $.057^{* * *}$ & $.043^{* *}$ & $.038^{*}$ & $.055^{\star * *}$ \\
\hline Home resources & $.126^{* * *}$ & $.199^{* * *}$ & $.128^{* * *}$ & $.142^{* * *}$ & $.126^{* * *}$ \\
\hline Gender & $.061^{* *}$ & $.084^{* * *}$ & $.060^{* * *}$ & $.112^{* * *}$ & $.108^{* * *}$ \\
\hline \multicolumn{6}{|c|}{ School entry skills ON } \\
\hline Cognitive activities & $.237^{* * *}$ & $.217^{* * *}$ & $.280 * * *$ & $.281^{* * *}$ & $.298^{* * *}$ \\
\hline Parental attitude & $.097^{* * *}$ & $.080^{* * *}$ & .004 & $.090^{* * *}$ & $.067^{* * *}$ \\
\hline Home resources & $.134^{* * *}$ & $.178^{* * *}$ & $.134^{* * *}$ & $.103^{* * *}$ & $.245^{\star * *}$ \\
\hline Gender & $-.099 * * *$ & $-.065^{* * *}$ & $-.096^{* * *}$ & $-.072^{* * *}$ & $-.018^{* *}$ \\
\hline \multicolumn{6}{|c|}{ Cognitive activities $\mathrm{ON}$} \\
\hline Parental attitude & $.099 * * *$ & $.173^{* * *}$ & $.189^{* * *}$ & $.117^{* * *}$ & $.141^{* * *}$ \\
\hline Home resources & $.327^{* * *}$ & $.256^{* * *}$ & $.181^{* * *}$ & $.392 * * *$ & $.304^{* * *}$ \\
\hline Gender & .018 & $.029^{*}$ & $-.068^{* * *}$ & .002 & -.018 \\
\hline \multicolumn{6}{|l|}{ School-level } \\
\hline \multicolumn{6}{|c|}{ School-mean science achievement ON } \\
\hline Academic success ${ }^{d}$ & $.258^{*}$ & $.310^{*}$ & $.419^{* *}$ & .128 & $.378^{* * *}$ \\
\hline Discipline problems & .195 & -.036 & .093 & $.375^{* * *}$ & -.052 \\
\hline School entry skills e & .018 & $.321^{*}$ & -.089 & .064 & .134 \\
\hline \multicolumn{6}{|c|}{ School emphasis on academic success ON } \\
\hline School entry skills & $.430^{\star * *}$ & $.279 * * *$ & .150 & $.329 * * *$ & $.351^{* * *}$ \\
\hline \multicolumn{6}{|c|}{ Discipline problems $\mathrm{ON}$} \\
\hline School entry skills & .121 & $.176^{*}$ & .152 & .172 & $.253^{* * *}$ \\
\hline \multicolumn{6}{|c|}{ Variance explained (\%) } \\
\hline Within level & 20.0 & 30.9 & 23.4 & 26.5 & 34.3 \\
\hline Between level & 11.5 & 25.6 & 18.5 & 18.2 & 19.2 \\
\hline
\end{tabular}

Noted. * refers to $p<.05 ;{ }^{* *}$ refers to $p<.01 ;{ }^{* * *}$ refers to $p<.001$.

$\mathrm{HK}=$ Hong Kong; KOR = South Korea; JP = Japan; TP = Chinese Taipei; SIG = Singapore.

a. reported by parents; b. home educational resources; c. parental attitude toward mathematics/science; d. school emphasis on academic success; e. reported by principles

together with Home educational resources and Selfconcept, were much stronger predictors of science achievement compared to the other student-level variables. The Wald test revealed that the direct effect of School entry skills on science achievement for the five regions was non-invariant $\left(\chi^{2}=69.998, p<.001\right)$. According to the path coefficients (Table 5 and Figure 2), the influence of School entry skills and science achievement was stronger for Singapore students, followed by Japanese, Hong Kong, South Korean and Chinese Taipei students.

For indirect effects, the results of the Hong Kong model indicated that School entry skills significantly positively and directly influenced Interest and Selfconcept, which subsequently influenced science achievement. The South Korea, Chinese Taipei, and Singapore models showed similar findings that School entry skills solely directly influenced Self-concept and subsequently science achievement. The Japan model, however, reported inconsistent findings that School entry skills did not have an impact on science achievement through either Interest or Self-concept. Wald tests for testing the invariance of the indirect effect of School entry skills on science achievement revealed significant differences in the indirect effect via Selfconcept $\left(\chi^{2}=20.068, p<0.001\right)$. The indirect effect via 


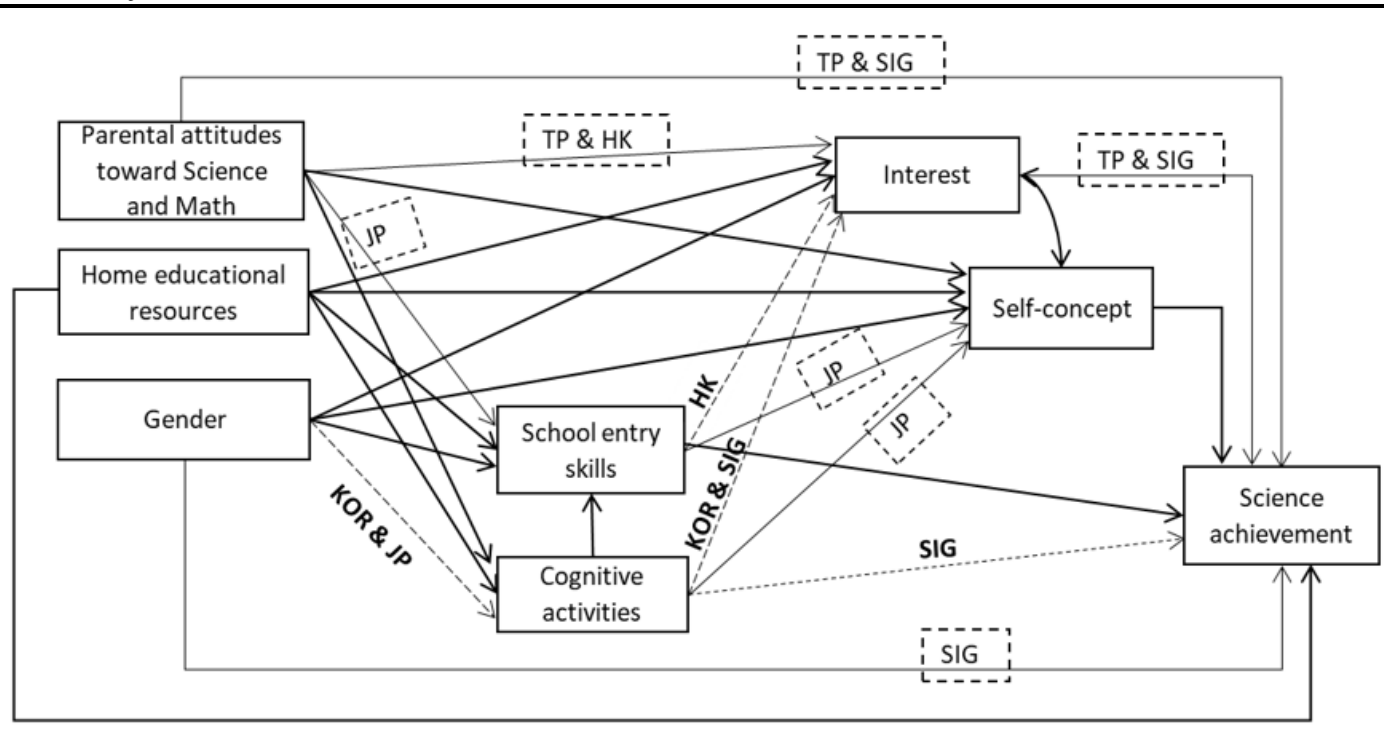

Student level

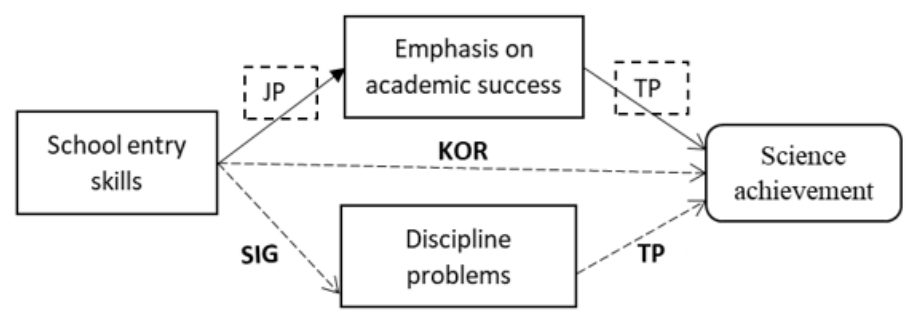

School level

Figure 2. Path analysis models of science achievement for the five Asian regions

(Noted: $\mathrm{HK}=$ Hong Kong; KOR = South Korea; JP = Japan; TP = Chinese Taipei; SIG = Singapore. "solid line" refers to significantly positive path; "dotted line" refers to non-significant path; "solid line + texts in dotted outline" means that the path was statistically significant, except for these regions; and "dotted line + texts in bold" means that the path mostly was nonsignificant, except for these regions.)

Interest was invariant among students for the five regions $\left(\chi^{2}=7.53, p>0.05\right)$.

Comparing the total effects and the indirect effects, less than $15 \%$ of the total effect of School entry skills was indirect, suggesting that School entry skills contributed to science achievement mainly directly in Asian regions.

\section{School Entry Skills as the Mediator at the Student Level}

It was noted that how School entry skills mediated the relationship between Family support (Cognitive activities, Parental attitudes toward mathematics and science, and Home educational resources) and science achievement varied across regions.

The influence of Cognitive activities on science achievement was fully mediated by School entry skills in the Japan model $\left(\beta_{J P}=.066\right)$. In the other four models, Cognitive activities affected science achievement through School entry skills $\left(\beta_{T P}=0.052 ; \beta_{H K}=0.061 ; \beta_{K O R}\right.$ $\left.=.041 ; \beta_{\text {SIG }}=.091\right)$, much greater than through Selfconcept $\left(\beta_{T P}=0.013 ; \beta_{H K}=0.010 ; \beta_{K O R}=.018 ; \beta_{\text {SIG }}=.008\right)$ or Interest $\left(\beta_{K O R}=.003\right)$. These results suggested that greater School entry skills were the main mediator

through which Cognitive activities were linked to science achievement.

The influence of parental attitudes toward mathematics and science on science achievement would be due to School entry skills, Cognitive activities, and Self-concept. In the Chinese Taipei and Singapore models, full mediations through School entry skills $\left(\beta_{T P}\right.$ $\left.=0.025 ; \beta_{\text {SIG }}=.020,\right)$, Cognitive activities $\left(\beta_{T P}=0.007 ; \beta_{\text {SIG }}\right.$ $=.007$,$) , and Self-concept \left(\beta_{T P}=0.010 ; \beta_{S I G}=.011, \beta_{H K}=\right.$ $\left.0.009 ; \beta_{K O R}=.012, \beta_{I P}=.005\right)$ were found. Parental attitudes influenced science achievement indirectly, suggesting that for Chinese Taipei and Singapore students, if their parents expressed more positive attitudes toward mathematics/science, they might have been engaged in more cognitive activities and have done better on literacy and numeracy tasks, and this would have increased their confidence and achievement in learning science. In the Hong Kong and South Korea models, despite Parental attitudes influencing science achievement mainly directly $\left(\beta_{H K}=0.041 ; \beta_{K O R}=.048, \beta_{J P}\right.$ $=.020)$, they showed significant, positive and indirect impacts through School entry skills $\left(\beta_{H K}=0.024 ; \beta_{K O R}=\right.$ $.016)$, Cognitive activities $\left(\beta_{H K}=0.006 ; \beta_{\text {KOR }}=.010\right)$ and Self-concept $\left(\beta_{H K}=0.009 ; \beta_{K O R}=.012\right)$ or Interest $\left(\beta_{H K}=\right.$ 
0.065). The Japan model demonstrated that the influence of Parental attitudes was mediated by School entry skills and Cognitive activities together $\left(\beta_{J P}=.012\right)$, as well as Self-concept $\left(\beta_{I P}=.005\right)$. Compared to the indirect effects via other variables, the indirect effect via School entry skills was to some extent greater, indicating the more important role of School entry skills in mediating the relationship between Parental attitudes and science achievement.

Moreover, the influence of Home educational resources on science achievement was mainly direct $\left(\beta_{T P}\right.$ $\left.=.331 ; \beta_{H K}=.179 ; \beta_{J P}=.296 ; \beta_{K O R}=.306 ; \beta_{S I G}=.354\right)$, but also partially mediated by School entry skills $\left(\beta_{T P}=.019\right.$; $\left.\beta_{H K}=.035 ; \beta_{I P}=.031 ; \beta_{K O R}=.033 ; \beta_{\text {SIG }}=.075\right)$, Cognitive activities $\left(\beta_{T P}=.025 ; \beta_{H K}=.022 ; \beta_{J P}=.012 ; \beta_{K O R}=.015 ; \beta_{\text {SIG }}\right.$ $=.013)$, Self-concept $\left(\beta_{T P}=.036 ; \beta_{H K}=.022 ; \beta_{J P}=.015 ; \beta_{K O R}\right.$ $\left.=.042 ; \beta_{\text {SIG }}=.026\right)$ or Interest $\left(\beta_{I P}=.005\right)$. Overall, Home education resources had small, significant, indirect and positive impacts on science achievement. These findings suggested that richer home educational resources were linked more to cognitive activities, resulting in higher literacy and numeracy abilities, and subsequently higher confidence, interest and/or achievement in studying science. Comparing the indirect effects via these variables, it was found that School entry skills were the main mediator for Home resources and science achievement in the Hong Kong, Japan, and Singapore models, while Self-concept was the major mediator in the Chinese Taipei and South Korea models.

\section{School-level Factors and Science Achievement}

The influence of School entry skills on science achievement differed across the Asian regions. School entry skills were found to show direct impacts on School-mean science achievement in the South Korea model, but not in the other models. Wald tests for the invariance of the path from School entry skills to science achievement were not statistically significant $\left(\chi^{2}=4.911\right.$, $p>0.05)$, indicating that the indirect effect of School entry skills on School-mean science achievement was invariant across the regions. Compared to School entry skills, science achievement appeared to be more significantly influenced by School emphasis on academic success, which showed a larger direct effect on the school level of Science achievement.

The indirect impacts of School entry skills on Schoolmean science achievement was more through School emphasis on academic success. This was found in the Hong Kong, South Korea, and Singapore models. This means that, in these regions, schools might place more emphasis on academic success when more students with adequate literacy and numeracy skills enter the school. When schools emphasise academic success, their students would exhibit high achievement in science learning. In the Japan and Chinese Taipei models, no such mediation was found. According to the Wald tests, the results showed that the indirect effects via Emphasis on academic success were non-invariant $\left(\chi^{2}=12.088, p<\right.$ 0.05).

\section{The Variance Explained by Each Model for Each Region}

Table 6 presents the variance of science achievement explained by each model for each Asian region. Respectively, the models for South Korea and Singapore explained $30.9 \%$ and $34.4 \%$ of the variance in achievement at the student level and $25.6 \%$ and $19.2 \%$ of the variance in achievement at the school level. The explained variances in the Chinese Taipei and Japan models were smaller, with $26.5 \%$ and $23.4 \%$ of the variance explained at the student level and $18.2 \%$ and $18.5 \%$ of the variance explained at the school level. The model for Hong Kong explained $20.0 \%$ and $11.5 \%$ of the variance in achievement at the student and school levels, respectively. Overall, these models accounted for 31.5\% to $56.4 \%$ of the variance in achievement at both levels for the five Asian regions.

\section{DISCUSSION}

This section discusses the role of school entry skills in literacy and numeracy skills in influencing science achievement among Grade 4 students at both the student and school levels. These findings have implications for home support and school education for improving students' science performance.

\section{Key Role of School Entry Skills on Individual Students}

Compared to Interest or Self-concept, School entry skills were found to be more strongly and positively associated with East Asian students' science achievement in this study. That is, students who had cognitive and numeracy skills at the point of school entry before schooling in these Asian areas were more likely to perform excellently in science learning. This association was found to be the strongest for Singapore students. This may be the result of parents or schools' emphasis on preparing young children for education in primary schools. In order to maximise children's readiness for school, formal kindergartens generally provide children with early formal instruction of literacy and numeracy skills, and parents have a high level of home-based involvement, such as reading stories to their children, or assisting their children in completing homework (Lau \& Rao, 2011).

It was also noted that school entry skills were positively linked to self-concept in learning science, whereas they did not strongly predict Interest of students. The findings can be found in four regions, but not Hong Kong. One explanation for this, presented by Sha, Schunn, Bathgatem, and Ben-Eliyahu (2016), is that parents underestimate the importance of stimulating students' interest in learning science. Sha et al. (2016) 
suggested that educators should attach more importance to motivation because it will drive student career choices in their future, and families should be willing to foster their children's cognitive development, but also cognitively and affectively engage in their children's learning activities at home.

\section{Cognitive Activities vs. Skills Acquisition}

Previous research has highlighted 'tiger' parenting (Fu \& Markus, 2014), pervasive out-of-school tutoring (Bray \& Kwok, 2003), and the culture in which education is highly valued (Francis \& Archer, 2005) as explanations for Asian students' high academic performance. For instance, South Korean parents always provide good studying environments so as to ensure that their children are able to concentrate on academic work (Park \& Kim, 2006). Similarly, Hong Kong parents prefer to facilitate their children's learning through communicating with them about school matters, and engaging them in academic-related activities, as well as providing them with educational and cultural resources at home (Lam \& Lau, 2014). Overall, Asian parents may become more academically-focused so as to maximise their children's academic achievement in primary schools.

This study also suggests the importance of family support for students' learning, with evidence that Home resources for learning were found to greatly affect science achievement. The findings were the same across the five regions. In addition, this study extended previous studies by providing evidence that in most Asian regions, School entry skills played the central role in mediating the relations of Cognitive activities, Parental attitudes, and Home educational resources with science achievement.

It is particularly worth noting that the role of Cognitive activities in science achievement was fully mediated by School entry skills in most of the Asian regions. That is, cognitive activities might show positive impacts on students' later science performance unless these activities successfully developed their literacy and numeracy skills. One possible explanation for the inconsistent results of this study with those reported in previous studies (e.g. Zhu \& Chiu, 2019) was that the link between skills and achievements was not within subject, but across subjects. It seems more important that students develop abilities of applying reading and mathematics skills that they gained prior to schooling to solve science-related problems. This study, therefore, suggests that parents should pay more attention to developing their children's capabilities in reading and mathematics, rather than arranging too many cognitive activities for them. The case of Japan showed that even without long hours spent on out-of-school mathematics activities, students' achievement levels can still remain among the highest (Komatsu \& Rappleye, 2018). Engagement in quality cognitive activities has more profound impacts on students' development and achievement.

\section{Academic Levels of Student Intake vs. School Expectations of Academic Success}

It was evident in these models that School entry skills had indirect impacts on school average science scores via school emphasis on academic success. That is, enrolling more students with literacy and numeracy skills helped to stimulate schools' expectations of academic success, which in turn allowed these schools to achieve higher academic performance. This is consistent with Lam and Lau (2014), who highlighted the important role of the academic level of school student intake, or ultimately, the school admission system, in school average achievement in science.

Despite this, it is encouraging to note that school level of science achievement was more directly influenced by emphasis on academic success or discipline problems. Given the current formal education system in Asian regions, schools, where students spend much of their time learning, play a prominent role in students' achievement (Eccles, Lord, \& Midgley, 1991). For schools to be effective, it makes sense that they should emphasise students' academic success as well as provide an orderly environment. Hoy (2012) concluded that elementary schools with strong academic expectations positively affect the achievement of poor and minority students. Marks (2010) reported that students achieved more when they studied in schools where disciplinary problems were not serious. If schools have considerable disciplinary problems such as late arrival or absenteeism, it is more likely that they will not be conducive to higher student achievement (Mohammadpour, 2013). Therefore, this study suggests that rather than overemphasising the quality of the student intake, it is more valuable for Asian schools to create a more favourable learning environment for students, where students are able to improve their learning.

\section{CONCLUSION}

Through exploring the complexity in the links from several student and school level factors to the science performance of fourth-grade students using the TIMSS 2015 data, this study revealed that the acquisition of key skills in literacy and numeracy is of particular importance for Asian students' science achievement. For most of the five Asian regions, students with higher parental reported literacy and numeracy skills appeared to perform better in their later science learning. They might be more confident in learning science, which would also influence their academic achievement. Additionally, it was found that literacy and numeracy skills generally played a central role in mediating the relation between Cognitive activities, Parental attitudes, 
as well as Home educational resources. At the school level, School entry skills were mostly found to have indirect impacts on School average scores in science through increasing School emphasis on academic success. Finally, it is important to note a few limitations of the current study. First, this study did not test the invariance of associations between factors in addition to school entry skills with science achievement among the models. Further research may consider examining whether certain associations in the models are invariant among different regions to gain a better understanding of the difference in the contribution of each variable to achievement in different contexts. Second, the variances in achievement explained by the models of this study in Hong Kong, Japan, and Chinese Taipei were less than $50 \%$. Further research may include other variables to better explain the variances in achievement in these regions.

\section{ACKNOWLEDGEMENTS}

The work was partially supported by grants from the Central Reserve Allocation Committee and the Faculty of Education and Human Development of The Education University of Hong Kong (Project No. 03A28).

\section{REFERENCES}

Barnard-Brak, L., Stevens, T., \& Ritter, W. (2017). Reading and mathematics equally important to science achievement: Results from nationallyrepresentative data. Learning and Individual Differences, 58, 1-9. https://doi.org/10.1016/ j.lindif.2017.07.001

Blums, A., Belsky, J., Grimm, K., \& Chen, Z. (2017). Building links between early socioeconomic status, cognitive ability, and math and science achievement. Journal of Cognition and Development, 18(1), 16-40. https://doi.org/10.1080/15248372. 2016.1228652

Boulifa, K., \& Kaaouachi, A. (2015). The relationship between the home resources for learning and sciences achievement in TIMSS 2011 A multilevel analysis, Applied Mathematical Sciences, 9(13), $637-$ 652. https:/ / doi.org/10.12988/ams.2015.48668

Bray, M., \& Kwok, P. (2003). Demand for private supplementary tutoring: Conceptual considerations, and socio-economic patterns in Hong Kong. Economics of Education Review, 22, 611-620. https: / / doi.org/10.1016/S0272-7757(03)00032-3

Byun, S. -Y., Kim, K. K., \& Park, H. (2012). School choice and educational inequality in South Korea. Journal of School Choice, 6(2), 158-183. https:/ / doi.org/10.1080/15582159.2012.673854

Chen, Q. (2014). Using TIMSS 2007 data to build mathematics achievement model of fourth graders in Hong Kong and Singapore. International Journal of Science and Mathematics Education, 12(6), 15191545. https:/ / doi.org/10.1007/s10763-013-9505-x

Claessens, A., \& Engel, M. (2013). How important is where you start? Early mathematics knowledge and later school success. Teachers College Record, 115, 1-29.

Cohen, J. (1988). Statistical power analysis for the behavioural sciences. London: Routledge. https:/ / doi.org/10.1002/bs.3830330104

Davies, S., Janus, M., Duku, E., \& Gaskin, A. (2016). Using the Early Development Instrument to examine cognitive and non-cognitive school readiness and elementary student achievement. Early Childhood Research Quarterly, 35, 63-75. https://doi.org/10.1016/j.ecresq.2015.10. 002

Davoudzadeh, P., McTernan, M. L., \& Grimm, K. J. (2015). Early school readiness predictors of grade retention from kindergarten through eighth grade: A multilevel discrete-time survival analysis approach. Early Childhood Research Quarterly, 32, 183-192. https://doi.org/10.1016/j.ecresq.2015.04. 005

De la Fuente, J., Sander, P., \& Putwain, D. (2013). Relationship between undergraduate student confidence, approach to learning and academic performance: The role of gender. Journal of Psychodidactics, 18(2), 373-391. https://doi.org/ 10.1387/RevPsicodidact.7078

Dearing, E., Mccartney, K., \& Taylor, B. A. (2009). Does higher quality early child care promote low-income children's math and reading achievement in middle childhood? Child Development, 80, 13291349. https://doi.org/10.1111/j.1467-8624.2009. 01336.x

Dierkes, J. (2008). Japanese shadow education: The consequences of school choice. In M. Forsey, S. Davies, \& G. Walford (Eds.), The globalisation of school choice? (pp. 231-248). Oxford: Symposium Books Ltd. https:/ / doi.org/10.15730/books.70

Duncan, G. J., Dowsett, C. J., Claessens, A., Magnuson, K., Huston, A. C., Klebanov, P., ... \& Sexton, H. (2007). School readiness and later achievement. Developmental psychology, 43(6), 1428. https:/ / doi.org/10.1037/0012-1649.43.6.1428

Duschl, R. A., Schweingruber, H. A., \& Shouse, A. W. (Eds.). (2007). Taking science to school: Learning and teaching science in grades K-8. Washington, DC: The National Academies Press. https://doi.org/ $10.17226 / 11625$

Eccles, J. S., Lord, S., \& Midgley, C. (1991). What are we doing to early adolescents? The impact of educational contexts on early adolescents. American Journal of Education, 99(4), 521-542. https:/ / doi.org/10.1086/443996 
Foy, P. (2017). TIMSS 2015 user guide for the international database. Chestnut Hill, MA: TIMSS and PIRLS International Study Center, Boston College and International Association for the Evaluation of Educational Achievement (IEA). Retrieved from https:/ / timssandpirls.bc.edu/timss2015/internati onal-database/downloads/T15_UserGuide.pdf

Fu, A., \& Markus, H. (2014). My mother and me: Why tiger mothers motivate Asian Americans but not European Americans. Personality and Social Psychology Bulletin, 40, 739-749. https://doi.org/ $10.1177 / 0146167214524992$

Grabau, L. J., \& Ma, X. (2017) Science engagement and science achievement in the context of science instruction: a multilevel analysis of U.S. students and schools, International Journal of Science Education, 39(8), 1045-1068. https://doi.org/ 10.1080/09500693.2017.1313468

Graham, J. W. (2009). Missing data analysis: Making it work in the real world. Annual Review of Psychology, 60, 549-576. https://doi.org/10.1146/annurev. psych.58.110405.085530

Grolnick, W.S., Friendly, R., \& Bellas, V. (2009). Parenting and children's motivation at school. Handbook of motivation at school. In K. R. Wenzel \& A. Wigfield (Eds.), Hand-book of motivation at school (pp. 279-300). New York, NY: Routledge/Taylor \& Francis. https://doi.org/ 10.4324/9780203879498

House, D. J., \& Telese, J. A. (2013). Mathematics instruction and achievement of eighth-grade students in Korea: Results from the TIMSS 2007 assessment. Education, 134(2), 266- 270.

Hoy, W. K. (2012). School characteristics that make a difference for the achievement of all students: A 40year academic odyssey. Journal of Educational Administration, 50, 76-97. https://doi.org/10.1108/ 09578231211196078

Huntsinger, C. S., Jose, P. E., \& Luo, Z. (2016). Parental facilitation of early mathematics and reading skills and knowledge through encouragement of homebased activities. Early Childhood Research Quarterly, 37, 1-15. https://doi.org/10.1016/j.ecresq.2016.02. 005

Jeynes, W. (2008). What we should and should not learn from the Japanese and other East Asian education systems. Educational Policy, 22(6), 900-927. https:// doi.org/10.1177/0895904807310042

Katsuno, M. (2019). The relationship between teachers' working conditions and teacher quality. In $\mathrm{Y}$. Kitamura, T. Omomo, \& M. Katsuno (Eds.), Education in Japan: A comprehensive analysis of education reforms and practices (Vol. 47) (pp. 87-104). Singapore: Springer. https:/ / doi.org/10.1007/978981-13-2632-5_6
Ker, H. W. (2017). The effects of motivational constructs and engagements on mathematics achievements: A comparative study using TIMSS 2011 data of Chinese Taipei, Singapore, and the USA. Asia Pacific Journal of Education, 37(2), 135-149. https: / / doi.org/10.1080/02188791.2016.1216826

Kim, S., \& Lee, J. H. (2010). Private tutoring and demand for education in South Korea. Economic development and cultural change, 58(2), 259-296. https:/ / doi.org/10.1086/648186

Komatsu, H., \& Rappleye, J. (2018). Is exam hell the cause of high academic achievement in East Asia? The case of Japan and the case for transcending stereotypes. British Educational Research Journal, 44(5), 802-826. https:/ / doi.org/10.1002/ berj.3468

Lam, T. Y. P., \& Lau, K. C. (2014). Examining factors affecting science achievement of Hong Kong in PISA 2006 using hierarchical linear modeling. International Journal of Science Education, 36(15), 2463-2480. https://doi.org/10.1080/09500693. 2013.879223

Lau, E. Y., Li, H., \& Rao, N. (2011). Parental involvement and children's readiness for school in China. Educational Research, 53(1), 95-113. https:/ / doi.org/10.1080/00131881.2011.552243

Liou, P. Y. (2017). Profiles of adolescents' motivational beliefs in science learning and science achievement in 26 countries: Results from TIMSS 2011 data. International Journal of Educational Research, 81, 8396. https:// doi.org/10.1016/j.ijer.2016.11.006

Little, T. D. (2013). Longitudinal structural equation modeling. New York, NY: The Guilford Press.

Mahler, D., Großschedl, J., \& Harms, U. (2017). Using doubly latent multilevel analysis to elucidate relationships between science teachers' professional knowledge and students' performance. International Journal of Science Education, 39(2), 213-237. https://doi.org/10.1080/ 09500693.2016.1276641

Marks, G. N. (2010). What aspects of schooling are important? School effects on tertiary entrance performance. School Effectiveness and School Improvement, 21(3), 267-287. https://doi.org/ $10.1080 / 09243451003694364$

Martin, M. O., Mullis, I. V. S., \& Hooper, M. (2016). Methods and procedures in TIMSS 2015. Chestnut Hill, MA: Boston College, TIMSS \& PIRLS International Study Center. Zugriff am (Vol. 21). Retrieved from https://timssandpirls.bc.edu/ publications / timss/2015-methods /T15-Methodsand-Procedures-TIMSS-2015.pdf

Martin, M. O., Mullis, I. V., Foy, P., \& Hooper, M. (2017). TIMSS 2011 international results in science. Chestnut Hill, MA: TIMSS \& PIRLS International Study Center. Retrieved from http://timssand 
pirls.bc.edu/timss2015/international-results/wpcontent/uploads/filebase/full\%20pdfs/T15International-Results-in-Science.pdf

Mohammadpour, E. (2013). A three-level multilevel analysis of Singaporean eighth-graders science achievement. Learning and Individual Differences, 26, 212-220

https:/ / doi.org/10.1016/j.lindif.2012.12.005

Mohammadpour, E., Shekarchizadeh, A., \& Kalantarrashidi, S. A. (2015). Multilevel modeling of science achievement in the TIMSS participating countries. The Journal of Educational Research, 108(6), 449-464. https://doi.org/10.1080/00220671.2014. 917254

Omomo, T. (2019). Primary and secondary education. In Y. Kitamura, T. Omomo, \& M. Katsuno (Eds.), Education in Japan: A comprehensive analysis of education reforms and practices (Vol. 47) (pp. 35-40). Singapore: Springer. https:/ / doi.org/10.1007/978981-13-2632-5_2

Park, Y. S., \& Kim, U. (2006). Family, parent-child relationship, and academic achievement in Korea. Indigenous and Cultural Psychology, 421-443. https://doi.org/10.1007/0-387-28662-4_19

Parker, P. D., Schoon, I., Tsai, Y. M., Nagy, G., Trautwein, U., \& Eccles, J. S. (2012). Achievement, agency, gender, and socioeconomic background as predictors of postschool choices: A multicontext study. Developmental Psychology, 48(6), 16291642. https:/ / doi.org/10.1037/a0029167

Rutkowski, L., Gonzalez, E., Joncas, M., \& von Davier, M. (2010). International large-scale assessment data: Issues in secondary analysis and reporting. Educational Researcher, 39, 142-151. https:/ / doi.org/10.3102/0013189X10363170

Segers, E., Kleemans, T., \& Verhoeven, L. (2015). Role of parent literacy and numeracy expectations and activities in predicting early numeracy skills. Mathematical Thinking and Learning, 17(2-3), 219-236. https:/ / doi.org/10.1080/10986065.2015.1016819

Sha, L., Schunn, C., Bathgate, M., \& Ben-Eliyahu, A. (2016). Families support their children's success in science learning by influencing interest and selfefficacy. Journal of Research in Science Teaching, 53(3), 450-472. https://doi.org/10.1002/ tea. 21251

Shanley, L., Clarke, B., Doabler, C. T., Kurtz-Nelson, E., \& Fien, H. (2017). Early number skills gains and mathematics achievement: Intervening to establish successful early mathematics trajectories. The Journal of Special Education,51(3), 177-188. https:/ / doi.org/10.1177/0022466917720455

Skwarchuk, S. L., Sowinski, C., \& LeFevre, J. A. (2014). Formal and informal home learning activities in relation to children's early numeracy and literacy skills: The development of a home numeracy model. Journal of Experimental Child Psychology, 121(1), 63-84. https:/ / doi.org/10.1016/j.jecp.2013. 11.006

Sun, L., Bradley, K. D., \& Akers, K. (2012). A multilevel modelling approach to investigating factors impacting science achievement for secondary school students: PISA Hong Kong sample. International Journal of Science Education, 34(14), 2107-2125. https://doi.org/10.1080/09500693. 2012.708063

Thomas, J. A., \& Strunk, K. K. (2017). Expectancy-value and children's science achievement: Parents matter. Journal of Research in Science Teaching, 54(6), 693-712. https://doi.org/10.1002/tea.21382

Topçu, M. S., Erbilgin, E., \& Arikan, S. (2016). Factors predicting Turkish and Korean Sstudents' science and mathematics achievement in TIMSS 2011. EURASIA Journal of Mathematics, Science $\mathcal{E}$ Technology Education, 12(7), 1711-1737. https:/ / doi.org/10.12973/eurasia.2016.1530a

Tsai, L. T., \& Yang, C. C. (2015). Hierarchical effects of school-, classroom-, and student-level factors on the science performance of eighth-grade Taiwanese students. International Journal of Science Education, 37(8), 1166-1181. https://doi.org/10.1080/ 09500693.2015.1022625

Vidovich, L., \& Sheng, Y. M. (2008). Global-local dynamics in expanding school choice in Singapore. In M. Forsey, S. Davies, \& G. Walford (Eds.), The globalisation of school choice? (pp. 209-230). Oxford: Symposium Books Ltd. https://doi.org/10.15730/ books.70

Walgermo, B. R., Foldnes, N., Uppstad, P. H., \& Solheim, O. J. (2018). Developmental dynamics of early reading skill, literacy interest and readers' selfconcept within the first year of formal schooling. Reading and writing,31(6), 1379-1399. https:/ / doi.org/10.1007/s11145-018-9843-8

Wang, C. L., \& Liou, P. Y. (2017). Students' motivational beliefs in science learning, school motivational contexts, and science achievement in Taiwan. International Journal of Science Education, 39(7), 1-20. https:/ / doi.org/10.1080/09500693.2017.1310410

Wang, J., \& Wang, X. (2012). Structural equation modeling: Applications using Mplus. Beijing: Hier Education Press. https:/ / doi.org/10.1002/9781118356258

Wang, Z., \& Bergin, D. A. (2017). Perceived relative standing and the big-fish-little-pond effect in 59 countries and regions: Analysis of TIMSS 2011 data. Learning and Individual Differences, 57(October 2015), 141-156. https://doi.org/10.1016/j.lindif. 2017.04.003

Yang, S. (1998). A study on competitions of education in Asia Confucius societies. NSC Report, No: NS187- 
2418-M-003-S14. http://www.ntcu.edu.tw/hsin_ hong/200802dissertation/24_6.pdf

$\mathrm{Yu}, \mathrm{C}$. H. (2012). Examining the relationships among academic self-concept, instrumental motivation, and TIMSS 2007 science scores: A cross-cultural comparison of five East Asian countries/regions and the United States. Educational Research and
Evaluation, 18(8), 713-731. https:// doi.org/10.1080 /13803611.2012.718511

Zhu, J., \& Chiu, M. M. (2019). Early home numeracy activities and later mathematics achievement: Early numeracy, interest, and self-efficacy as mediators. Educational Studies in Mathematics, 102(2), 173-191. https:/ / doi.org/10.1007/s10649-019-09906-6

\section{APPENDIX A}

The Variables Used in this Study

\begin{tabular}{ll}
\hline Variables & The TIMSS 2015 scales \\
$\begin{array}{l}\text { Student level } \\
\text { Interest }\end{array}$ & $\begin{array}{l}\text { The Students Like to Learn Science (LLS) with } 9 \text { items } \\
\text { measuring the degree of enjoyment in learning science } \\
\text { among students. }\end{array}$ \\
Self-concept & $\begin{array}{l}\text { The Student Confident in Science scale (SCS) with } 7 \text { items } \\
\text { measuring how well students perceive their abilities in } \\
\text { learning science. }\end{array}$ \\
$\begin{array}{l}\text { School entry skills - } \\
\text { reported by parents }\end{array}$ & $\begin{array}{l}\text { The Could Do Early Literacy and Numeracy Tasks (LNT) } \\
\text { scale with 11 items exploring students' abilities in } \\
\text { performing several literacy and numeracy tasks based on } \\
\text { their parents' responses. }\end{array}$
\end{tabular}

Sample items

Sample items

"I enjoy learning science", "I like science”,

"I like to do science experiments" (4 =

"agree a lot" to 1 = "disagree a lot")

(Martin et al., 2016).

"I usually do well in science" "I learn

things quickly in science", "My teacher tells me I am good at science" ( 4 = "agree a lot" to $1=$ "disagree a lot") (Martin et al., 2016).

"Recognise most of the letters of the alphabet" $(4=$ "Very Well" to $1=$ "Not at

All") , "Count by himself/herself" $(4=$ "Up

to 100 or higher" to $1=$ "Not at all"), "Do

simple addition" $(1=$ Yes and $0=$ No)

(Martin et al., 2016).

Cognitive activities The Early Literacy and Numeracy Activities scale (ELN) with "Reading books", "telling stories", “Write 16 items exploring the frequency of doing literacy and numeracy activities by students based on their parents' responses.

Parental attitude The Parental Attitude Toward Mathematics and Science (AMS) scale with 8 items exploring how parents value mathematics and science. numbers" ( 3 = Often, 2 = Sometimes, 1 = Never or almost never) (Martin et al., 2016).

"Science and technology can help solve the world's problems", "Science explains how things in the world work", "Learning science is for everyone" $(4=$ "agree a lot" to $1=$ "disagree a lot") (Martin et al., 2016).

Home resources The Home resources for learning (HRL) scale with 5 items measuring the availability of learning resources (e.g. books, internet) at home based on students' and parents' responses.

Gender "Number of books in home" "highest level of education of either parent(parents)"

"highest level of occupation of either parent(parents)" (Martin et al., 2016). 0 for girls and 1 for boys.

\section{School-level}

School emphasis on The School Emphasis on Academic Success (EAS) with 13 academic success items investigating teachers' expectations and parents' support for student achievement, and students' desire for high achievement based on principals' responses.

School discipline problems

The School Discipline Problems (DAS) with 10 items exploring potential school problems such as lateness to school, cheating, and classroom disturbance based on principals' responses.

School entry skills - The Schools Where Students Enter the Primary Grades with reported by principals
Literacy and Numeracy Skills (LNS) scale with 11 items exploring the percentage of children in the school who begin first grade with key literacy and numeracy skills based on their principals' responses.
“Teachers' expectations for student achievement", "Parental involvement in school activities", "Students' desire to do well in school $(5=$ "very high" to $1=$ "very low") (Martin et al., 2016).

"arriving late at school”, "classroom disturbance", "physical fights among students" $(4=$ "serious problem" to $1=$ "not a problem") (Martin et al., 2016).

"Reading books", "telling stories", "Write numbers" $(4=$ More than 75\%, $3=51 \%$ -

$75 \%, 2=25 \%-50 \%, 1=$ Less than $25 \%$ )

(Martin et al., 2016).

\section{http://www.ejmste.com}

